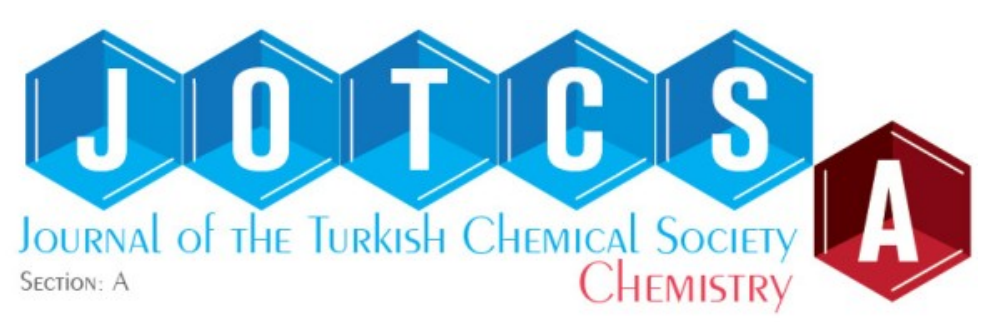

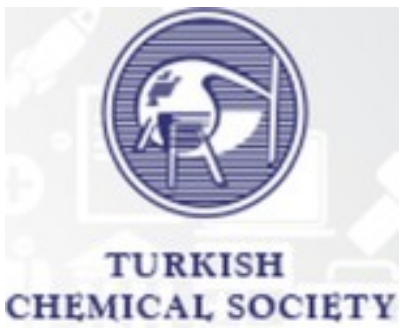

\title{
Antioxidant and Anticholinesterase Properties of Sideritis perfoliata subsp. athoa (Papan. \& Kokkini) Baden and Sideritis trojana Bornm. Teas from Mount Ida-Turkey and Their Phenolic Characterization by LC- MS/MS
}

\author{
Sema CARIKCI* \\ *Izmir Democracy University, Vocational School, 35140, Izmir, Turkey
}

\begin{abstract}
The phenolic profile, antioxidant, and anticholinesterase activities of teas prepared from two Sideritis (L.) species: Sideritis perfoliata subsp. athoa (Papan. \& Kokkini) Baden and Sideritis trojana Bornm., collected from Mount Ida (Kaz Dağı) Turkey, were determined. The teas were prepared by infusion and decoction methods. The quantitative amounts of the phenolic contents were determined by liquid chromatography-tandem mass spectrometry (LC-MS/MS). The significant phytochemicals were found to be fumaric acid for infusion and decoction samples of S. trojana and infusion of S. perfoliata subsp. athoa, chlorogenic acid for decoction of S. perfoliata subsp. athoa. The tea samples prepared by the decoction method were found to be rich in phenolics. Apart from the fact that the decoction sample of $S$. trojana exhibited the best antioxidant effect in 2,2-diphenyl-1-picrylhydrazyl (DPPH), $\beta$-carotene bleaching and cupric $\left(\mathrm{Cu}^{2+}\right)$ ion reducing power assay (CUPRAC) methods among the tested samples at all concentrations, and showed significant inhibition effect at $200 \mu \mathrm{g} / \mathrm{mL}$ against acetylcholinesterase and butyrylcholinesterase enzymes $(59.74 \%, 64.99 \%$, respectively).
\end{abstract}

Keywords: Sideritis, Sideritis perfoliata subsp. athoa (Papan. \&Kokkini) Baden, Sideritis trojana Bornm., Antioxidant activity, Anticholinesterase activity, Phenolics.

Submitted: April 11, 2020. Accepted: June 15, 2020.

Cite this: CARIKCI S. Antioxidant and Anticholinesterase Properties of Sideritis perfoliata subsp. athoa (Papan. \& Kokkini) Baden and Sideritis trojana Bornm. Teas from Mount Ida-Turkey and Their Phenolic Characterization by LC-MS/MS. JOTCSA. 2020;7(2):617-32.

DOI: https://doi.org/10.18596/jotcsa.718274.

*Corresponding author. E-mail: sema.carikci@idu.edu.tr.Tel:+90 232 2621001. Fax:+90 2322621004.

\section{INTRODUCTION}

For centuries, herbal teas have been used as herbal remedies to treat infections, ailments, and diseases. For the usage as a health-promoting beverage, the evaluation of the functional and bioactive composition of the tea, such as polyphenols, carotenoids, vitamin $C$, vitamin $E$, as well as essential major, minor, and trace elements are essential. Some studies have been reported their antioxidative, antimicrobial, anticarcinogenic, antihypertensive, antimutagenic, and antiangiogenic activities. These activities have shown that they are related to different bioactive components included in herbal teas (1-4).
The antioxidant activity is based on the availability of electrons to neutralize any free radicals. Phenolic compounds are known to be antioxidant compounds. The antioxidant activity of plants is attributed mainly to their phenolic compounds $(1,3-$ 4). Alzheimer's disease (AD) is the most common form of dementia. In addition to synthetic drugs, the treatment of this disease has gained significant importance with natural treatments. Therefore, finding natural sources to inhibit acetylcholinesterase (AChE) and butyrylcholinesterase (BChE), which $A D$ begins as a deficiency in the production of the neurotransmitter acetylcholine inhibitors, has been the subject of many studies recently. 
The genus Sideritis (L.), a member of the Lamiaceae plant family, is distributed mainly in the Mediterranean area over 150 annual and perennial species $(5,6)$. In Turkey, as well as in the world, Sideritis species is very widely consumed as herbal tea and has been used in folk medicine for their activities such as anti-inflammatory, antirheumatic, antispasmodic, and antimicrobial (7-11). In Turkey, the genus Sideritis is divided into three sections (Hesiodia, Burgsdorfia, and Empedoclia), and Turkey is the gene center of the Empedoclia section (5). They represented 46 species (52 taxa) with a very high endemism ratio (almost $80 \%$ ) (9). Most of the studies carried on Sideritis species are focused on their bioactive constituents; essential oils, diterpenoids, glycosides- and activities of their extracts, and isolated pure compounds (1,3,6-13). Although they have been used as a tea for a long time, the studies of aqueous extracts of the genus Sideritis have recently become more popular. Traditionally, Sideritis teas are prepared via the infusion method using flowering branches of the plant. The studies showed that the main chemicals of the infusions are composed of water-soluble polyphenolic compounds, many of which have related to their potent antioxidant properties, also minerals and vitamins. The phytochemical composition and several activities of some Sideritis tea; Sideritis scardica, S. raeseri, S. syriaca, and S. clandestina subsp. clandestina have been reported previously $(1,3,15-17)$.

Mount Ida, which is one of the wealthiest mountains concerning rareness and endemic species, is located between Balikesir and Canakkale boundaries in Turkey. Sideritis perfoliata subsp. athoa (Papan. \& Kokkini) Baden., and S. trojana Bornm. are grown at Mount Ida. S. trojana is an endemic species, widely known as "Sarıkız çayı" and $S$. perfoliata subsp. athoa is known as "Kedi kuyruğu çayı". The teas prepared from both species are widely consumed with a view to its distinctive flavor and possible pharmacological effects such as common cold, including fever, flu, and bronchitis, and to relieve gastric disorders (18). Both species have been investigated for their essential oil, diterpenoids, and glycoside composition, and several activities in some studies (Table 1 ). There is no study on the detailed phenolic composition and anticholinesterase activity of teas prepared from $S$. trojana and S. perfoliata subsp. athoa.

The objective of the present study is to determine phenolic composition as well as antioxidant and anticholinesterase activity of the $S$. trojana and $S$. perfoliata subsp. athoa herbal teas. Two methods were used to prepare tea samples: infusion and decoction. The determined phenolic contents, divided of mainly three groups: flavonoids and derivatives, phenolic acids, and dicarboxylic acid, were screened by LC-MS/MS. Antioxidant properties were determined based on 2,2-diphenyl-1picrylhydrazyl (DPPH), $\beta$-carotene linoleic acid, and cupric $\left(\mathrm{Cu}^{2+}\right)$ ion reducing power assay (CUPRAC). The anticholinesterase activity was also evaluated. This study is the first one on the phenolic composition and activity of the $S$. trojana and $S$. perfoliata subsp. athoa herbal teas.

Table 1. Previous studies on S. trojana and S. perfoliata subsp. athoa.

\begin{tabular}{|c|c|c|}
\hline & S. trojana & S. perfoliata subsp. athoa \\
\hline $\begin{array}{l}\text { Major comp. of Essential } \\
\text { oil (EO) }\end{array}$ & $\begin{array}{l}\beta \text {-pinene } \\
\text { a-pinene (19) } \\
\text { Valeranone } \\
\text { a-bisabolol } \\
\beta \text {-caryophyllene (20) }\end{array}$ & $\begin{array}{l}\text { Myrcene } \\
\beta \text {-pinene } \\
\text { Ar-curcumene (25) }\end{array}$ \\
\hline Diterpenoids & $\begin{array}{l}\text { 7-epi-Candicandiol } \\
\text { Siderol } \\
\text { Sideridiol } \\
\text { Isocandol B } \\
\text { Candol A acetate } \\
\text { Ent-7a-acetoxy-kaur-15-ene } \\
\text { Ent-7a-acetoxy-15 } 16 \beta \text {-epoxy- } \\
\text { kaurane (7-Acetyl-sideroxol) } \\
\text { Ent-2a-hydroxy-8(14),15-pimaradiene } \\
(21)\end{array}$ & 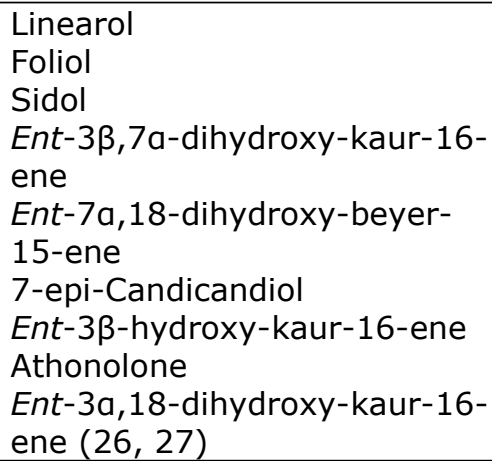 \\
\hline $\begin{array}{l}\text { Phenolics, Flavonoids and } \\
\text { derivatives }\end{array}$ & $\begin{array}{l}\text { Melittoside } \\
10-O-(E) \text {-feruloylmelittoside } \\
10-O-(E)-p \text {-coumaroylmelittoside } \\
\text { Stachysoside E } \\
\text { Stachysoside G } \\
\text { Verbascoside }\end{array}$ & \\
\hline
\end{tabular}




\begin{tabular}{|c|c|c|}
\hline & 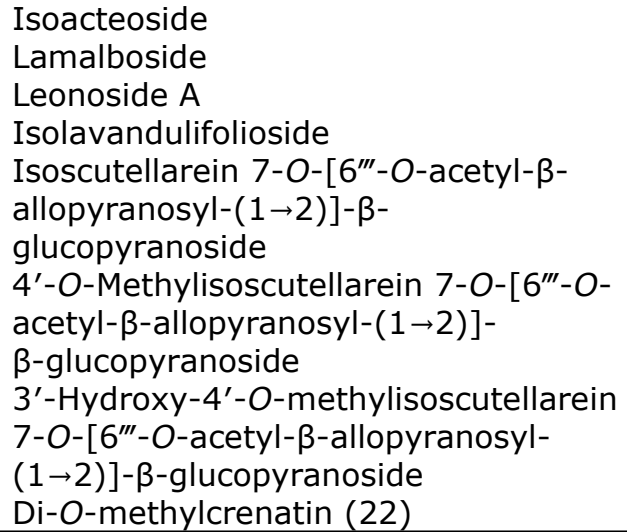 & \\
\hline Activity & $\begin{array}{l}\text { Antistress (23) } \\
\text { Antimicrobial activity of EO (20) } \\
\text { Antioxidant and antidiabetic activity } \\
\text { (24) }\end{array}$ & $\begin{array}{l}\text { Candida albicans Inhibitory } \\
\text { (28) } \\
\text { Insecticidal (29) }\end{array}$ \\
\hline
\end{tabular}

\section{MATERIALS AND METHODS}

\section{General}

LC-MS/MS experiments were performed by a Zivak $\AA$ HPLC and Zivak $\AA$ Tandem Gold Triple quadrupole (Istanbul, Turkey) mass spectrometry, equipped with a Synergy Max C18 column (250 x 2 $\mathrm{mm}$ i.d., 5- $\mu \mathrm{m}$ particle size). The compounds used as standards in LC-MS/MS analyses and the experimental details are given in the supplementary data. For the antioxidant and anticholinesterase activities, absorbances (UV and visible range of 230 $\mathrm{nm}$ to $750 \mathrm{~nm}$ ) were measured using a multiplate reader (Beckman Coulter DTX 880 Multimode Detector).

\section{Plant Material}

Sideritis perfoliata subsp.athoa (Papan. \&Kokkini) Baden. were collected from natural habitats in B1, Balikesir-Edremit, Mount Ida (Kazdağı, Kapıdağ), around the fire tower, rocky areas, 1350 m altitude, July 2013, Turkey (herbarium number TD 3805).

Sideritis trojana Bornm., originated in BalikesirEdremit, Mount Ida, near Sarıkız hill, limestone rocks, $1750 \mathrm{~m}$ altitude, July 2013, Turkey (herbarium number TD 3818). The species were identified by Prof. Dr. Tuncay Dirmenci (Balıkesir University), voucher specimens have been deposited at Balikesir University Necatibey Education Faculty Herbarium. The plant samples were allowed to dry in the shade.

\section{Preparation of decoction and infusion samples} Herbal teas were prepared as following the traditional preparation method: infusion and decoction.

Infusion: Two grams of the dried aerial parts of the plant were added in a beaker which contained 100 $\mathrm{mL}$ of distilled boiled water and allowed to stay for 15 minutes. Then it was filtered through Whatman No.1 filters (Sigma-Aldrich). The filtrate $(25 \mathrm{~mL})$ was diluted with $25 \mathrm{~mL}$ of distilled water.
Decoction: Two grams of the dried aerial parts of the plant were added to $100 \mathrm{~mL}$ of distilled water in a beaker and brought to boiling. After the boiling was stopped, the mixture was left for 15 min and filtered. The filtrate $(25 \mathrm{~mL})$ was diluted with $25 \mathrm{~mL}$ of distilled water.

Infusion samples were named as SPAI (infusion sample of $S$. perfoliata subsp. athoa (Papan. \& Kokkini) Baden.) and STI (infusion sample of $S$. trojana Bornm.), decoction was SPAD (decoction sample of $S$. perfoliata subsp. athoa (Papan. \& Kokkini) Baden.) and STD (decoction sample of $S$. trojana Bornm).

\section{Antioxidant Activities}

The antioxidant activity was evaluated using in vitro the free radical scavenging activity using 2,2diphenyl-1-picrylhydrazyl (DPPH·) (DPPH assay) (30), $\beta$-carotene-linoleic acid model system (31) and CUPRAC (32). BHT (butylated hydroxytoluene) and BHA (butylated hydroxyanisole) were used as standards in DDPH and $\beta$-carotene-linoleic acid assay. In CUPRAC assay ethanol was used as a negative control; whereas curcumin was used as a positive control. A detailed experimental procedure for the activity studies were given in the supplementary data.

\section{Anticholinesterase activity}

For the measurement of anticholinesterase activity, inhibition of AChE and BChE were measured by the slightly modified spectrophotometric method developed by Ellman, Courtney, Andres, and Featherston (33). A detailed procedure was given in supplementary material.

\section{LC-MS/MS experiments}

In the LC-MS/MS experiments the mobile phase was composed of water ( $A, 0.1 \%$ formic acid) in methanol ( $B, 0.1 \%$ formic acid), the gradient program of which was 0-1.00 minute $55 \% A$ and 45 
$\%$ B, 1.01-20.00 minutes $100 \%$ B and finally 20.01-23.00 $55 \% A$ and $45 \% \mathrm{~B}$. The flow rate of the mobile phase was $0.25 \mathrm{~mL} / \mathrm{min}$, and the column temperature was set to $30{ }^{\circ} \mathrm{C}$. The injection volume was $10 \mu \mathrm{L}$.

The mobile phase was composed to be a gradient of acidified methanol and water system because of its fragmented ion stability. The optimum ESI (Electrospray Ionization) parameters were identical to those described in the recent study (13-14). Detailed information, validation of experiments and uncertainty evaluation is given in supplementary data.

\section{Preparation of test solution for LC-MS/MS}

A one $\mathrm{mL}$ of each sample was added $4 \mathrm{~mL}$ of the ethanol-water mixture $(50: 50 \mathrm{v} / \mathrm{v})$. A portion of 1 $\mathrm{mL}$ of this stock solution was transferred into a $5 \mathrm{~mL}$ of another volumetric flask, and $50 \mathrm{~mL}$ of curcumin solution was added as internal standard and diluted to the volume with methanol and mixed. The solution was filtered through a $0.45 \mu \mathrm{m}$ Millipore Millex-HV filter and the final solution ( $1 \mathrm{~mL}$ ) was transferred into a capped auto sampler vial and 10 $\mathrm{mL}$ of sample was injected to LC for each run. The samples in the auto sampler were kept at $15^{\circ} \mathrm{C}$ during the experiment.

\section{Statistical Analysis}

In both antioxidant and anticholinesterase activity tests, the experimental data were calculated as the mean \pm standard deviation and analyzed. Variance ANOVA was studied, including one-way analysis. Significant differences between means were recorded by Duncan's multiple range tests. $p<0.05$ was regarded as significant, and $p<0.01$ was very significant.

\section{RESULTS AND DISCUSSION}

Table 2. Phenolic composition of Sideritis trojana and S. perfoliata subsp. athoa

\begin{tabular}{|c|c|c|c|c|}
\hline \multicolumn{5}{|c|}{ Flavonoids and derivatives } \\
\hline & SPAI & SPAD & STI & STD \\
\hline Rutin (1) & $1.64 \pm 0.11$ & - & $1.70 \pm 0.11$ & - \\
\hline Quercitrin (2) & - & $15.17 \pm 0.97$ & - & - \\
\hline Apigenin (3) & - & - & $12.17 \pm 0.98$ & $16.61 \pm 1.34$ \\
\hline Penduletin (4) & $16.73 \pm 1.7$ & $58.53 \pm 5.93$ & $2.92 \pm 0.3$ & $59.30 \pm 6.01$ \\
\hline $\begin{array}{l}\text { Quercetagetin-3,6-dimethylether } \\
\text { (5) }\end{array}$ & $110.87 \pm 20.76$ & - & - & $27.32 \pm 5.12$ \\
\hline Luteolin-7-O-glucoside (6) & $7.34 \pm 0.37$ & $22.26 \pm 2.27$ & - & $1.84 \pm 0.19$ \\
\hline Luteolin-5-O-glucoside (7) & - & $4.60 \pm 0.3$ & - & - \\
\hline Pelargonin (8) & $7.30 \pm 0.37$ & & $46.21 \pm 2.35$ & $47.86 \pm 4.87$ \\
\hline Total (mg/kg) & 143.88 & 100.56 & 63.00 & 152.93 \\
\hline \multicolumn{5}{|c|}{ Phenolic acids } \\
\hline p-Coumaric acid (9) & $2.65 \pm 0.41$ & - & - & - \\
\hline Caffeic acid (10) & $34.65 \pm 6.86$ & $28.36 \pm 5.61$ & $22.89 \pm 4.53$ & $15.53 \pm 3.07$ \\
\hline t-Ferulic acid (11) & $201.26 \pm 14.06$ & - & $107.32 \pm 7.5$ & - \\
\hline Chlorogenic acid (12) & $205.28 \pm 28.43$ & $210.89 \pm 29.2$ & $18.20 \pm 2.52$ & $184.86 \pm 25.6$ \\
\hline Rosmarinic acid (13) & $3.94 \pm 0.3$ & $3.73 \pm 0.29$ & $4.19 \pm 0.32$ & $4.57 \pm 0.35$ \\
\hline Gallic acid (14) & $4.65 \pm 0.32$ & $4.55 \pm 0.32$ & $4.63 \pm 0.32$ & $4.54 \pm 0.31$ \\
\hline Syringic acid (15) & - & $2.92 \pm 0.2$ & - & $28.80 \pm 1.94$ \\
\hline Total (mg/kg) & 452.43 & 250.945 & 157.23 & 218.30 \\
\hline \multicolumn{5}{|c|}{ Dicarboxylic acid } \\
\hline Fumaric acid (16) & $281.06 \pm 19.49$ & $206.49 \pm 14.32$ & $310.62 \pm 21.54$ & $462.14 \pm 32.05$ \\
\hline Total (mg/kg) & 281.06 & 206.49 & 310.62 & 462.14 \\
\hline Total (mg/kg) & 877.37 & 557.50 & 530.85 & 853.37 \\
\hline
\end{tabular}

Major compounds of the extracts showed as bold.

\section{Phenolic Profile}

The characterization of the phenolic components of decoction and infusion samples of $S$. perfoliata subsp. athoa and S. trojana was achieved by LC/MS analysis. The results were given in Table 2 . In the tea samples, around 10 to 12 phenolic compounds were determined. S. perfoliata subsp. athoa was found to be rich in phenolic acids, whereas $S$. 
trojana was rich in dicarboxylic acid. SPAI was found to be the richest in terms quantity $(877.37 \mathrm{mg} / \mathrm{kg})$ and numbers of determined components (12 phenolic compounds).

Fumaric acid was the main component for the infusion sample of Sideritis perfoliata subsp. athoa, infusion sample of $S$. trojana (STI) and decoction sample of $S$. trojana (STD) $(281.06,310.62,462.14$ $\mathrm{mg} / \mathrm{kg}$, respectively). For decoction sample of $S$. perfoliata subsp. athoa (SPAD), chlorogenic acid was determined as the main component $(210.89 \mathrm{mg}$ $/ \mathrm{kg}$ ). The three main components for tea samples were determined as follows: fumaric acid, chlorogenic acid, t-ferulic acid for SPAI; chlorogenic acid, fumaric acid, penduletin for SPAD; fumaric acid, t-ferulic acid, pelargonin for STI and fumaric acid, chlorogenic acid, penduletin for STD. It was previously shown that Sideritis extracts, especially methanolic, were rich in phenylpropanoids like verbascoside and martinoside; flavones like apigenin and penduletin; and flavone glucosides like isoscutellarein and hypolaetin $(12,13,34-36)$. In the aqueous extract, in addition to these compounds, mainly chlorogenic acid, ferulic acid, cinnamic acid, and caffeic acid, were determined $(3,15,37,35)$. The results are consistent with previous studies.

\section{Antioxidant and Anticholinesterase Activities}

Since a higher correlation between phenolics and antioxidant activity has been demonstrated by several studies in aromatic and medicinal plants (39-42), there is a growing interest in phenolic compounds and flavonoids, which are the most widely occurring chemicals in plants having strong antioxidant properties. Due to the toxic effect of synthetic derivatives humans prefer taking these compounds supplied by nutritional sources such as fruits, vegetables, and herbal tea, which have high phenolic content and good antioxidant capacity.

Antioxidant activities of teas were determined according to three methods: DPPH, $\beta$-carotene, and CUPRAC. The results are given in Table 3 . For DPPH and $\beta$-carotene, the activity tests were carried on four different concentrations: at $10 \mu \mathrm{g} / \mathrm{mL}, 25$ $\mu \mathrm{g} / \mathrm{mL}, 50 \mu \mathrm{g} / \mathrm{mL}, 100 \mu \mathrm{g} / \mathrm{mL}$. In the DPPH method, for all concentrations, SPAI, SPAD, and STD showed very high radical scavenging activity (up to 60\%), while STI had relatively lower activity. STI has showed the best inhibition activity at a concentration of $100 \mu \mathrm{g} / \mathrm{mL}$ with $42.34 \%$, while BHA was $62.39 \%$ and $\mathrm{BHT}$ was $80.82 \%$.

Considering that these three tea samples are rich in fumaric acid and chlorogenic acid, it can be said that these compounds are responsible for the significant antioxidant activity of the teas. Most studies on phenolic contents of herbal teas showed that the antioxidant activity of the teas could be attributed to the presence of phenolic compounds. Notably, the antioxidant capacities of the teas having chlorogenic acid were found to be reasonably high $(3,43,44)$. Although it is not a phenolic compound, fumaric acid is a compound commonly detected in plant extracts, and plants carrying this compound at a high amount have been found to exhibit high antimicrobial and antioxidant activity $(14,45)$. Furthermore, in the $\beta$ carotene-linoleic acid method, the SPAI has had the best activity value, like the standard BHA. In the CUPRAC, TEAC ${ }_{\text {CUPRAC }}$ values of the teas were calculated by using curcumin as a reference. TEAC $_{\text {CUPRAC }}$ of curcumin was found as $0.9 \mathrm{mmol}$ TR $\mathrm{g}^{-}$ ${ }^{1}$ (in Trolox $\mathrm{mM}$ equivalents of $1 \mathrm{mM}$ antioxidant solution which studied). The tea samples prepared by the decoction method were showed higher activity (for SPAD $2.21 \mathrm{mmol}$ TR $\mathrm{g}^{-1}$ and for STD $2.23 \mathrm{mmol}$ TR $\mathrm{g}^{-1}$ ), while the lowest activity was showed by STI $\left(0.43 \mathrm{mmol}\right.$ TR $\left.\mathrm{g}^{-1}\right)$, which was the lowest tea sample in terms of total phenolic content (Table 3).

The anticholinesterase activities of the tea samples were determined at a concentration of $200 \mu \mathrm{g} / \mathrm{mL}$, and inhibition \% values were calculated against $\mathrm{AChE}$ and $\mathrm{BChE}$ activities. The results are given in Table 4. AChE and BChE were inhibited by galantamine, which was used as a standard, at a rate of $86 \%$ and $77 \%$, respectively. Among the tea samples, the best inhibition values against the AChE enzyme were shown by STD of $59.74 \%$ and SPAI of $58.30 \%$. For the BChE enzyme, the results were similar. STD and SPAI had the best inhibition values; $64.99 \%$ and $53.60 \%$, respectively. STI has the lowest inhibition against both enzymes. Although the antioxidant activities of the tea samples resulted from their high phenolic acid contents, Orhan et al., (2007) (46) reported that there was no correlation between AChE and BChE enzyme inhibition with phenolic contents. They had reported that some of these compounds are not inhibitor for AChE and BChE. Rather than phenolic acids, flavonoid derivatives such as quercetin, genistein, luteolin-7-O-rutinoside were found to be more effective inhibitors. If the flavonoid content of the tea samples were compared, it was found that STD and SPAI samples with higher flavonoid content (in total 152.93 and $143.88 \mathrm{mg} / \mathrm{kg}$, respectively) were showed higher enzyme inhibition. STI, with the lowest amount of flavonoid content, has the lowest inhibition. These results are consistent with the literature. 


\begin{tabular}{|c|c|c|c|c|c|}
\hline \multirow{8}{*}{ 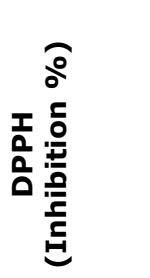 } & \multicolumn{5}{|c|}{ Table 3. Activity results of SPA and ST. } \\
\hline & & $10 \mu \mathrm{g} / \mathrm{mL}$ & $25 \mu \mathrm{g} / \mathrm{mL}$ & $50 \mu \mathrm{g} / \mathrm{mL}$ & $100 \mu \mathrm{g} / \mathrm{mL}$ \\
\hline & SPAD & $68.92 \pm 0.70$ & $68.98 \pm 0.68$ & $62.78 \pm 0.65$ & $65.83 \pm 0.30$ \\
\hline & STD & $69.38 \pm 0.93$ & $68.47 \pm 0.40$ & $65.92 \pm 0.90$ & $62.98 \pm 1.20$ \\
\hline & SPAI & $66.25 \pm 0.72$ & $67.31 \pm 2.70$ & $64.73 \pm 2.54$ & $62.33 \pm 1.24$ \\
\hline & STI & $4.88 \pm 0.84$ & $4.99 \pm 1.18$ & $8.85 \pm 2.63$ & $42.34 \pm 3.26$ \\
\hline & BHA & $22.75 \pm 2.15$ & $30.97 \pm 4.14$ & $48.17 \pm 3.94$ & $62.39 \pm 2.99$ \\
\hline & BHT & $73.09 \pm 2.62$ & $77.68 \pm 0.74$ & $78.79 \pm 0.76$ & $80.82 \pm 1.56$ \\
\hline \multirow{6}{*}{ 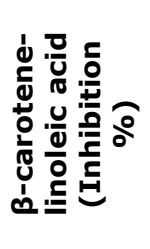 } & SPAD & $53.44 \pm 1.55$ & $61.27 \pm 1.12$ & $59.25 \pm 0.67$ & $47.82 \pm 0.23$ \\
\hline & STD & $70.47 \pm 1.55$ & $69.88 \pm 2.13$ & $66.34 \pm 2.15$ & $54.83 \pm 2.55$ \\
\hline & SPAI & $39.96 \pm 2.6$ & $85.87 \pm 0.46$ & $70.49 \pm 3.77$ & $76.95 \pm 0.54$ \\
\hline & STI & $5.77 \pm 1.45$ & $68.38 \pm 6.47$ & $54.72 \pm 1.73$ & $62.24 \pm 2.58$ \\
\hline & BHA & $81.90 \pm 1.95$ & $85.54 \pm 1.73$ & $85.98 \pm 2.42$ & $79.54 \pm 4.13$ \\
\hline & BHT & $82.56 \pm 5.03$ & $72.38 \pm 11.8$ & $77.12 \pm 2.93$ & $71.02 \pm 1.01$ \\
\hline \multirow{6}{*}{ 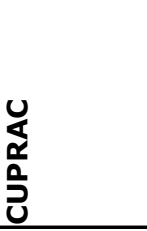 } & & $\mathrm{mmol} \mathrm{TR} / \mathrm{g}$ & & & \\
\hline & SPAD & 2.21 & & & \\
\hline & STD & 2.53 & & & \\
\hline & SPAI & 1.43 & & & \\
\hline & STI & 0.43 & & & \\
\hline & Curcumin & 0.90 & & & \\
\hline
\end{tabular}

Table 4 Anticholinesterase Activity of $S$. trojana and $S$. perfoliata subsp. athoa

\begin{tabular}{lcc}
\hline \multirow{2}{*}{ Tea Samples } & \multicolumn{2}{c}{ Anticholinesterase Activity } \\
\cline { 2 - 3 } & AChE & BChE \\
\hline SPAI & $58.30 \pm 0.48$ & $53.60 \pm 0.33$ \\
SPAD & $46.82 \pm 0.74$ & $32.40 \pm 0.22$ \\
STI & $30.06 \pm 0.67$ & $22.78 \pm 0.04$ \\
STD & $59.74 \pm 0.80$ & $64.99 \pm 0.36$ \\
Galantamine & $86.73 \pm 1.25$ & $77.13 \pm 1.48$ \\
\hline
\end{tabular}

$\%$ inhibition values at $200 \mu \mathrm{g} / \mathrm{mL}$ concentration of tea samples.

Galantamine was used as a standard. 


\section{CONCLUSION}

In conclusion, Sideritis perfoliata subsp. athoa and S. trojana were found as a crucial antioxidant source in different in vitro tests like $\mathrm{DPPH}, \beta$ carotene linoleic acid, and CUPRAC assays. Also, they have the best inhibition results on two enzymes, which have essential roles in Alzheimer's Disease. The quantities of some phenolics of the infusion and decoction of $S$. perfoliata subsp. athoa and $S$. trojana were successfully characterized by LC-MS/MS, and chlorogenic acid, t-ferulic acid, penduletin, and fumaric acid were determined as the most abundant chemicals for tea samples. The antioxidant and anticholinesterase activities of the S. perfoliata subsp. athoa and $S$. trojana were probably their phenolic and flavonoid composition. Furthermore, the activity could be attributed to the possible synergistic interaction between phenolic and non-phenolic components in its chemical composition. According to the results, it can be said that S. trojana and S. perfoliata subsp. athoa can be used as a supportive food for an antioxidant source for daily take.

\section{Supplementary data}

Method validation parameters of LC-MS/MS measurements, standards chromatogram of secondary metabolites, structures of the determined phenolics and procedures of biological activity assays can be found in the Supplementary Information section of this document.

\section{Conflict of interest}

The author declares no competing financial interest.

\section{Funding}

This research did not receive any specific grant from funding agencies in the public, commercial, or notfor-profit sectors.

\section{REFERENCES}

1. Irakli $M$, Tsifodimou $K$, Sarrou $E$, Chatzopoulou P. Optimization Infusions Conditions for Improving Phenolic Content and Antioxidant Activity in Sideritis scardica Tea Using Response Surface Methodology. J Appl Res Med Aromat Plants. 2018;8:67-74.

2. Silveira TFF da, Meinhart AD, Ballus CA, Godoy HT. The Effect of the Duration of Infusion, Temperature, and Water Volume on the Rutin Content in the Preparation of Mate Tea Beverages: An Optimization Study. Food Res Int. 2014;60:2415 .

3. Goulas V, Exarchou V, Kanetis L, Gerothanassis IP. Evaluation of the Phytochemical Content, Antioxidant Activity and Antimicrobial Properties of Mountain Tea (Sideritis syriaca) Decoction. J Funct Foods. 2013;6:248-58.
4. Ozer Z. Investigation of Phenolic Compounds and Antioxidant Activity of Mentha spicata L. subsp. spicata and M. Iongifolia (L.) subsp. typhoides (Briq.) Harley Decoction and Infusion. JOTCSA. 2018;5(2):445-56.

5. Güvenç A, Duman H. Morphological and Anatomical Studies of Annual Taxa of Sideritis $L$. (Lamiaceae), With Notes on Chorology in Turkey. Turk J Bot. 2010;34:83-104.

6. Obon de Castro C, Rivera-Nunez D. A Taxonomic revision of the section Sideritis genus Sideritis (Labiatae). In: Cramer J (Eds.), BerlinStuttgart, pp 86. 1994.

7. Fraga BM. Phytochemistry and Chemotaxonomy of Sideritis Species from the Mediterranean Region. Phytochemistry. 2012;76:724.

8. González-Burgos E, Carretero ME, GómezSerranillos MP. Sideritis spp.: Uses, Chemical Composition and Pharmacological Activities- A review. J Etnopharmacol. 2011;135:209-25.

9. Kilic T, Topcu G, Goren AC, Aydogmus Z, Karagoz A, Yildiz YK, Aslan I. Ent-kaurene Diterpenoids from Sideritis lycia with Antiviral and Cytotoxic Activities. Rec Nat Prod. 2020; 14(4):25668.

10. Çarıkçı S, Özer Z, Dereli S, Açar D, Gören AC, Kılıç T. Essential Oil Composition of Five Sideritis Species Endemic to Turkey. SDU J Nat Appl Sci. 2018;22(Special Issue):301-5.

11. Çarıkçı S, Kılıç T, Azizoğlu A, Topçu G. Chemical Constituents of Two Endemic Sideritis Species from Turkey with Antioxidant Activity. Rec Nat Prod. 2012;2:101-9.

12. Halfon B, Çiftçi E, Topçu G. Flavonoid Constituents of Sideritis caesarea. Turk J Chem. 2013;37:464-72.

13. Sagir ZO, Carikci S, Kilic T, Goren AC. Metabolic Profile and Biological Activity of Sideritis brevibracteata P. H. Davis Endemic to Turkey. Int J Food Prop. 2017;20(12):2994-3005.

14. Özer Z, Gören AC, Kılıç T, Öncü M, Çarıkçı S, Dirmenci, T. The Phenolic Contents, Antioxidant and Anticholinesterase Activity of Section Amaracus (Gled.) Vogel and Anatolicon Ietsw. of Origanum L. Species. Arab J Chem. 2020; 13:5027-39.

15. Vasilopoulou CG, Kontogianni VG, Linardaki ZI. Phytochemical Composition of "Mountain Tea" from Sideritis clandestina subsp. clandestina and Evaluation of Its Behavioral and Oxidant / Antioxidant Effects on Adult Mice. Eur J Nutr. 2013;107-16. 
16. Danesi $F$, Saha $S$, Kroon PA, Glibeti $M$. Bioactive-rich Sideritis scardica tea (Mountain Tea) is as Potent as Camellia sinensis Tea at Inducing Cellular Antioxidant Defences and Preventing Oxidative Stress. J Sci Food Agric. 2013:3558-64.

17. Petreska J, Stefova $M$, Ferreres $F$, Moreno DA, Tomás-barberán FA, Stefkov G, et al. Potential Bioactive Phenolics of Macedonian Sideritis species Used for Medicinal "Mountain Tea". Food Chem. 2011;125:13-20.

18. Selvi S, Dağdelen A, Kara S. Medicinal and Aromatic Plants Consumed as Herbal Tea and Collected from Ida Mountains (Balıkesir -Edremit). J Tekirdag Agricul Facul. 2013;10(2):26-33.

19. Kirimer N, Baser KHC, Demirci B, Duman $\mathrm{H}$. Essential Oils of Sideritis Species of Turkey Belonging to the Section Empedoclia. Chem Nat Compd. 2004; 40:18-21.

20. Kirmizibekmez $H$, Karaca $N$, Demirci $B$, Demirci F. Characterization of Sideritis trojana Bornm. Essential Oil and Its Antimicrobial Activity. Marmara Pharm J. 2017; 21(4): 860-5.

21. Topçu G, Gören A, Kılıç T, Yıldız YK, Tümen G. Diterpenes from Sideritis trojana. Nat Prod Lett. 2002; 16:33-7.

22. Kirmizibekmez $H$, Ariburnu $E$, Masullo $M$, Festa M, Capasso A, Yesilada E, Piacente S. Iridoid, Phenylethanoid and Flavonoid Glycosides from Sideritis trojana. Fitoterapia. 2012; 83:130-6.

23. Oztürk $\mathrm{Y}$, Aydin $\mathrm{S}$, Öztürk $\mathrm{N}$, Başer $\mathrm{KHC}$. Effects of Extracts from Certain Sideritis Species on Swimming Performance in Mice. Phytotherapy Res 1996; 10:70-3.

24. Celep $E$, Seven $M$, Akyüz $S$, İnan $Y$, Yesilada $E$. Influence of Extraction Method on Enzyme Inhibition, Phenolic Profile and Antioxidant Capacity of Sideritis trojana Bornm. S Afr J Bot. 2019; 121:360-5.

25. Özek T, Baser KHC. The Essential Oil of Sideritis athoa Papanikolaou et Kokkini. J Essent Oil Res. 1993; 5:669-70.

26. Kilic T, Goren AC, Tumen G, Topcu G. Phytochemical Analysis of Some Sideritis Species of Turkey. Chem Nat Comp. 2003;39:373-374.

27. Topçu G, Gören AC, Yildiz YK, Tümen G. Ent-kaurene Diterpenes from Sideritis athoa. Nat Prod Lett. 1999; 14(2):123-9.

28. Dulger B, Gonuz A, Aysel V. Inhibition of Clotrimazole-resistant Candida albicans by Some
Endemic Sideritis Species from Turkey. Fitoterapia. 2006; 77:404-5.

29. Aslan I, Kılıç T, Gören AC, Topçu G. Toxicity of Acetone Extract of Sideritis trojana and (Say), Sitophilus granarius (L.) and Ephestia kuehniella (Zel.). Ind Crop Prod. 2006; 23:171-6.

30. Blois MS. Antioxidant Determinations by the Use of A Stable Free Radical. Nature.1958;181:1199-1200.

31. Marco GJ. A Rapid Method for Evaluation of Antioxidants. J American Oil Chem Soc. 1968; 45:594-8

32. Apak R, Güclü K, Özyürek M, Celik S E. Mechanism of Antioxidant Capacity Assays and the CUPRAC (cupric ion reducing antioxidant capacity) assay. Microchimica Acta. 2008;160(4):413-9.

33. Ellman $G L$, Courtney $K D$, Andres $V$, Featherston RM. A New and Rapid Colorimetric Determination of Acetylcholinesterase Activity. Biochem Pharmacol 1961; 7: 88-95.

34. Charami MT, Lazari D, Karioti A, Skaltsa H, Hadjipavlou-Litina D, Souleles C. Antioxidant and Antiinflammatory Activities of Sideritis perfoliata subsp. perfoliata (Lamiaceae). Phytother Res. $2008 ; 22: 450-4$

35. Gabrieli CN, Kefalas PG, Kokkalou EL. Antioxidant Activity of Flavonoids from Sideritis raeseri. J Etnopharmacol 2005; 96:423-8.

36. Kirmizibekmez $H$, Ariburnu $E$, Masullo $M$, Festa M, Capasso A, Yesilada E, et al. Iridoid, Phenylethanoid and Flavonoid Glycosides from Sideritis trojana. Fitoterapia. 2012;83(1):130-6.

37. Deveci E, Tel-çayan G, Duru ME. Phenolic Profile, Antioxidant, Anticholinesterase, and Antityrosinase Activities of the Various Extracts of Ferula elaeochytris and Sideritis stricta. Int J Food Prop 2018; 21:771-83.

38. Zengin G, Sarikurkcu C, Aktumsek A. Sideritis galatica Bornm.: A Source of Multifunctional Agents for the Management of Oxidative Damage, Alzheimer's and Diabetes Mellitus. J Funct Foods. 2014; 11:538-47.

39. Baki S, Tufan AN, Altun M, Özgökçe F, Güçlü $K$, Özyürek M. Microwave-assisted Extraction of Polyphenolics from Some Selected Medicinal Herbs Grown in Turkey. Rec Nat Prod. 2018; 12(1), 29.

40. Yılmaz $H$, Çarıkçı $S$, Kılıç $T$, Dirmenci $T$, Arabacı T, Gören AC. Screening of Chemical Composition, Antioxidant and Anticholinesterase Activity of Section Brevifilamentum of Origanum (L.) Species. Rec Nat Prod. 2017; 5:439-55. 
41. Gülçin İ. Antioxidant Activity of Food Constituents: An Overview. Arch Toxicol 2012; 86(3):345-91.

42. Vergine $M$, Nicolì $F$, Negro $C$, Luvisi $A$, Nutricati $E$, Accogli RA, Sabella $E$, Miceli A. Phytochemical Profiles and Antioxidant Activity of Salvia species from Southern Italy. Rec Nat Prod. 2019; 13(3):205-15.

43. Erkan N, Cetin H, Ayranci E. Antioxidant Activities of Sideritis congesta Davis et HuberMorath and Sideritis arguta Boiss et Heldr.: Identification of Free Flavonoids and Cinnamic Acid Derivatives. Food Res Int. 2011;44(1):297-303.
44. Silva BA, Malva O, Dias ACP. St. John's Wort (Hypericum perforatum) Extracts and Isolated Phenolic Compounds are Effective Antioxidants in Several in Vitro Models of Oxidative Stress. Food Chem. 2008;110:611-19.

45. Jaberian H, Piri K, Nazari J. Phytochemical Composition and in Vitro Antimicrobial and Antioxidant Activities of Some Medicinal Plants. Food Chem. 2013; 136(1):237-44.

46. Orhan I, Kartal M, Tosun F, Şener B. Screening of Various Phenolic Acids and Flavonoid Derivatives for Their Anticholinesterase Potential. Z Naturforsch C 2007; 62(11-12):829-32. 


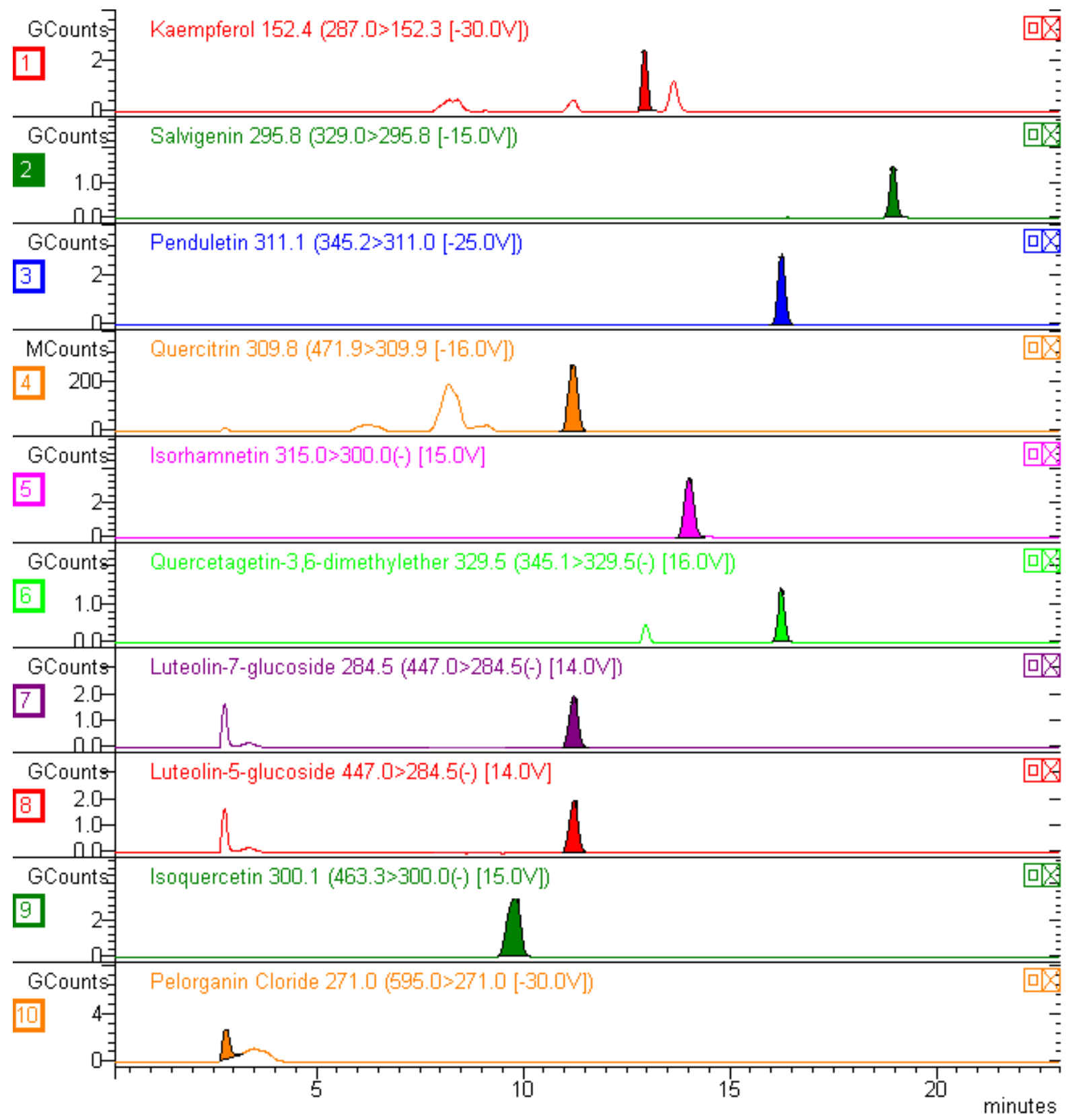

Figure S1 : Standards Chromatogram of Secondary Metabolites (Flavonoids) by LC-MS/MS (5 mg/L) 


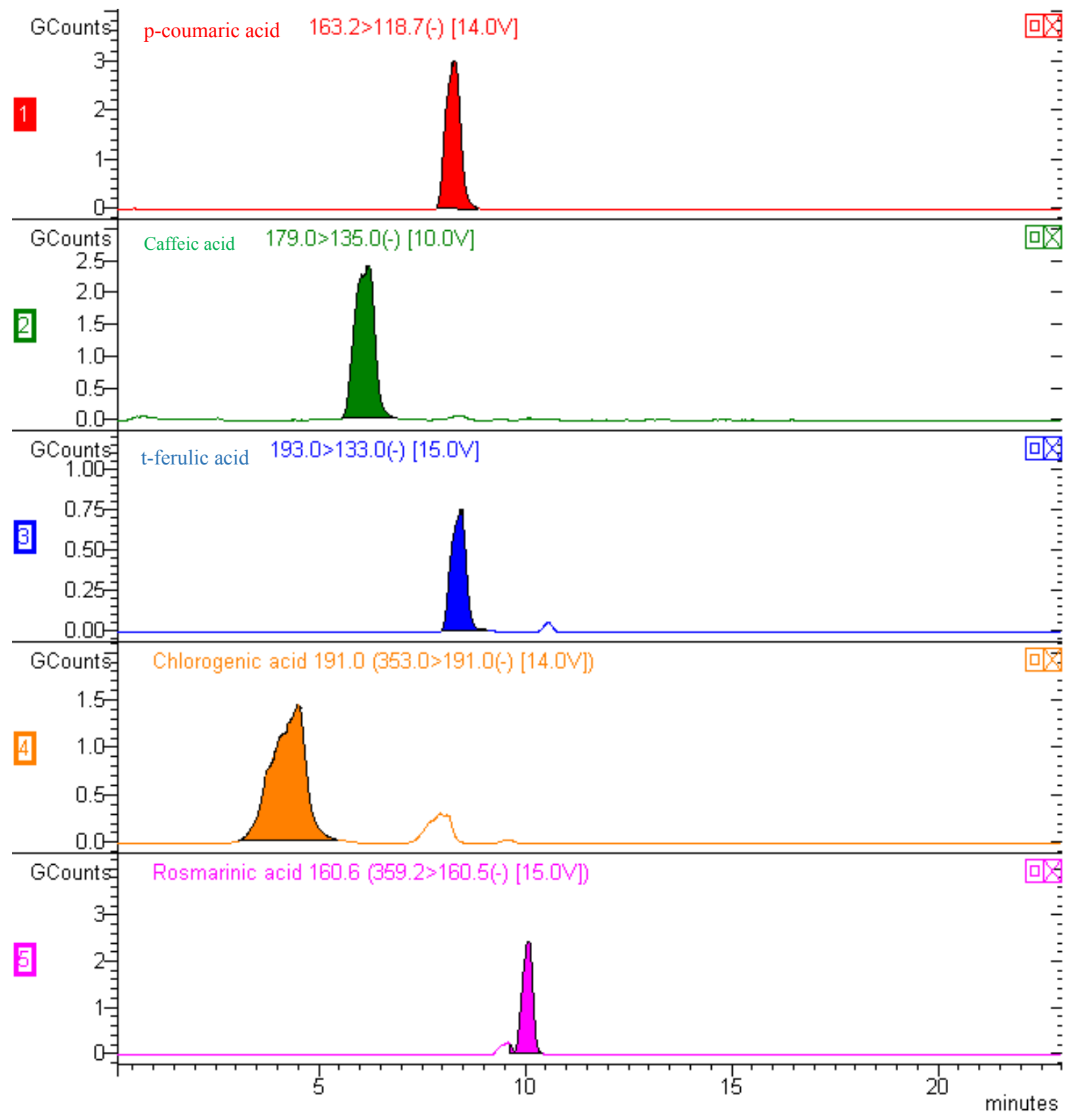

Figure S2: Standards Chromatogram of Secondary Metabolites (Phenolics and Others) by LC-MS/MS (5 $\mathrm{mg} / \mathrm{L})$ 


\section{Figure S2 (Continued)}

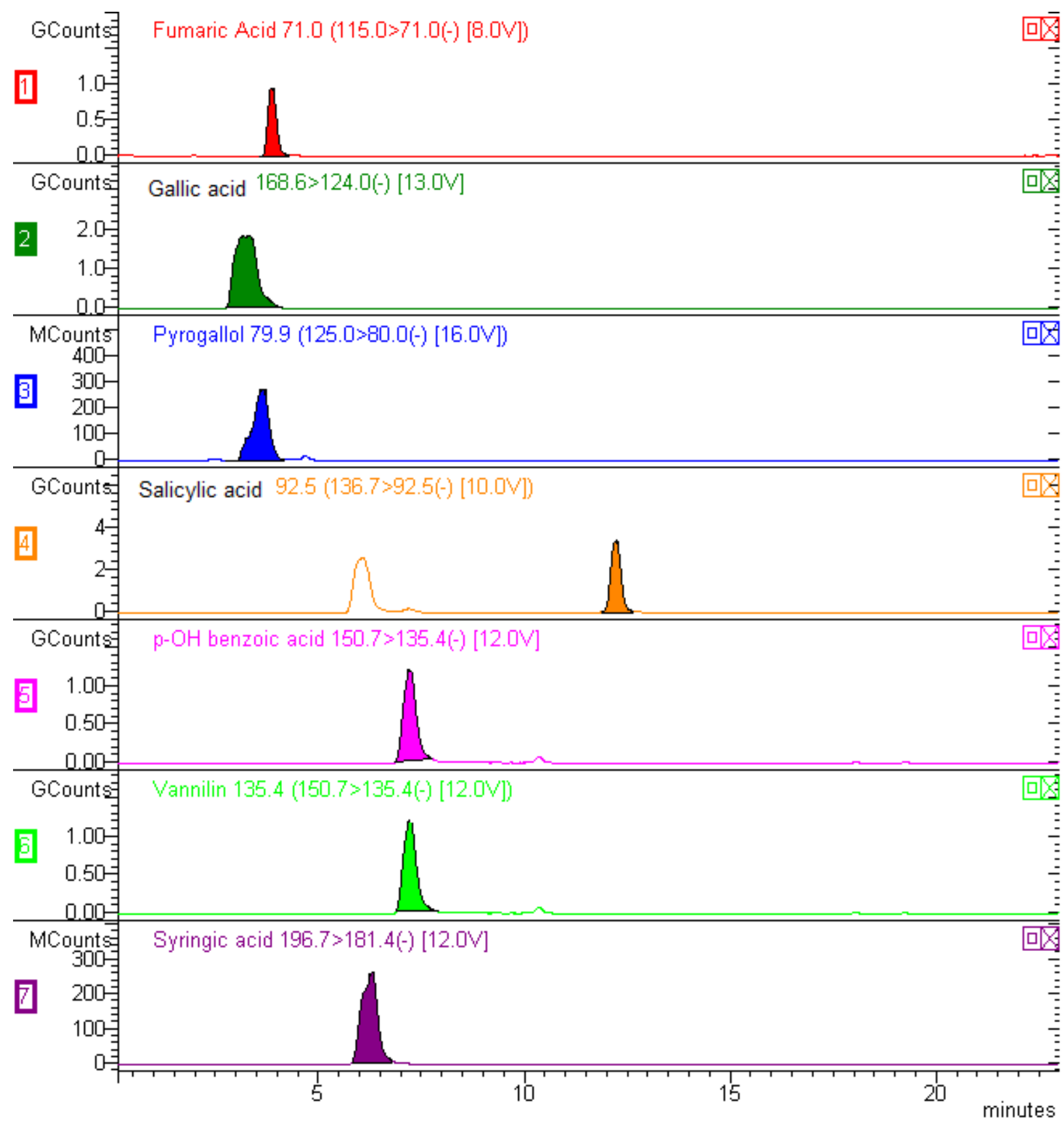


CARIKCI S. JOTCSA. 2020; 7(2): 617-634.

Table S2. Structures of the determined phenolics

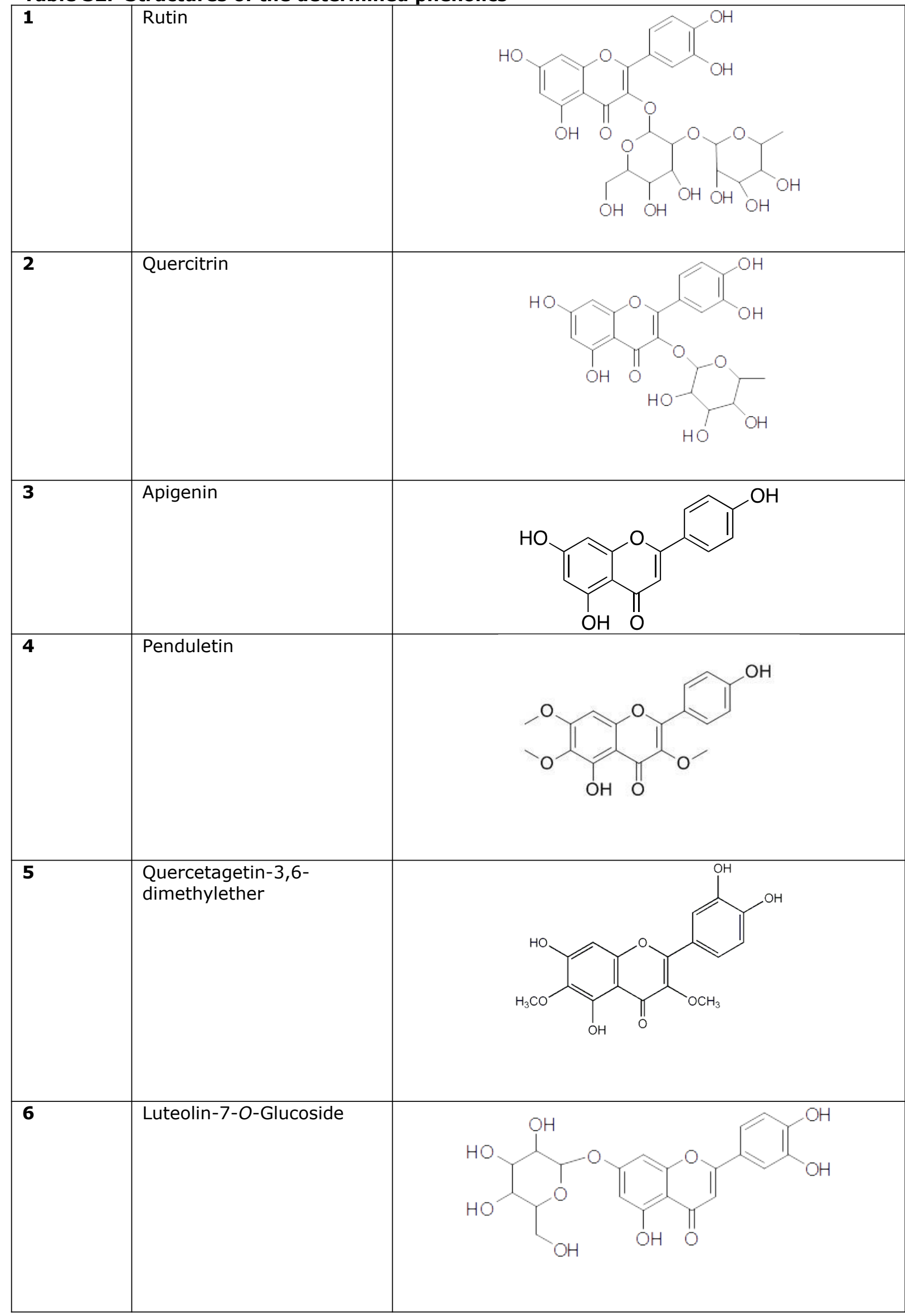




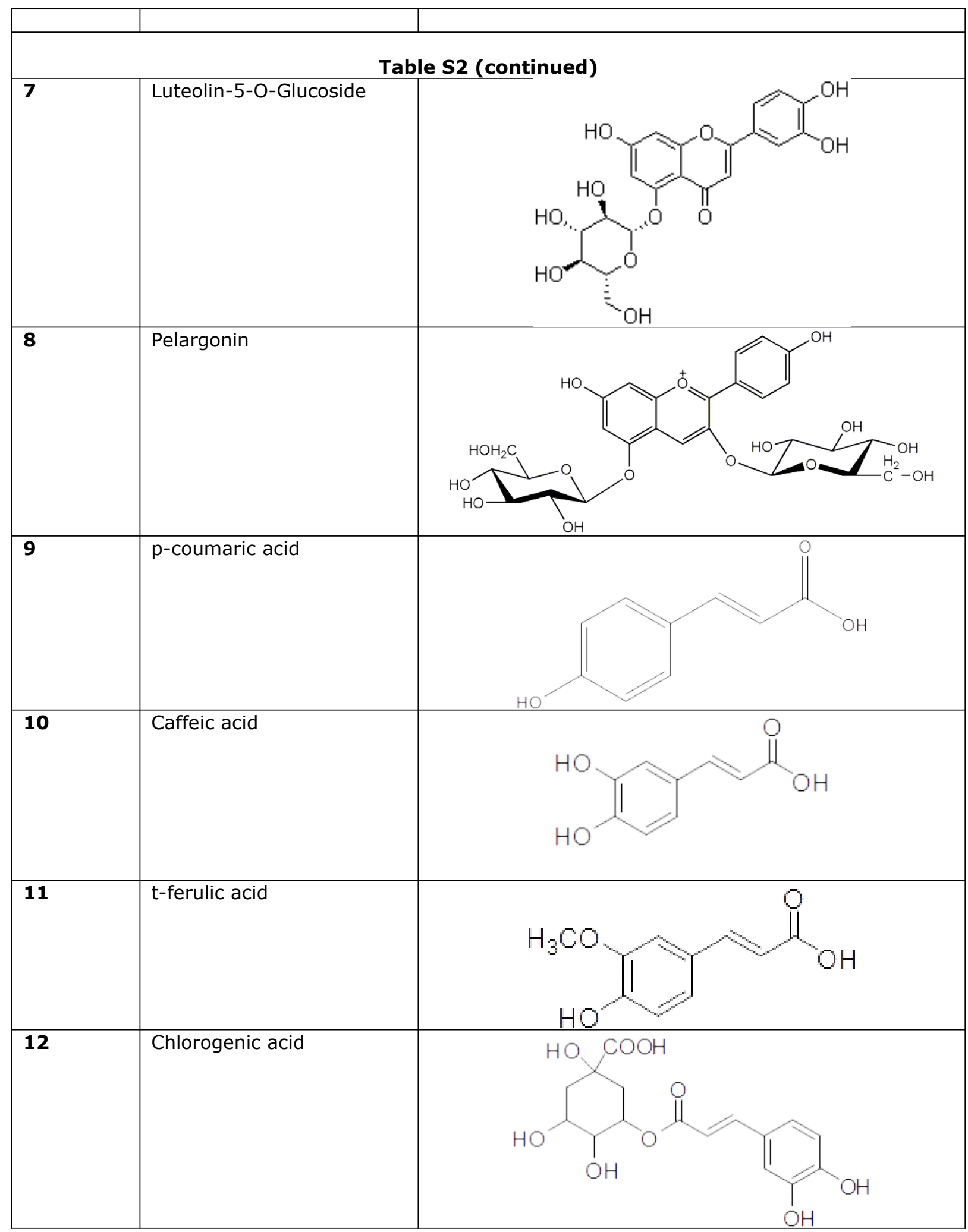




\begin{tabular}{|l|l|l|}
\hline $\mathbf{1 4}$ & Gallic acid & Table S2 (continued) \\
\hline $\mathbf{1 5}$ & Syringic acid & \\
\hline $\mathbf{1 6}$ & Fumaric acid & \\
\hline $\mathbf{I S}$ & Curcumin-IS & \\
\hline
\end{tabular}

\section{MATERIAL AND METHODS}

\section{Chemicals}

The following compounds were used as standards in LC-MS/MS analyses: fumaric acid (99\%, SigmaAldrich), pyrogallol (98\%, Sigma-Aldrich), rutin (94\%, Sigma-Aldrich), chlorogenic acid (95\%, SigmaAldrich), gallic acid (99\%, Merck), syringic acid (95\%, Sigma-Aldrich), t-ferulic acid (99\%, Sigma-Aldrich), caffeic acid (98\%, Sigma-Aldrich), pelargonin chloride (98\%, Sigma-Aldrich), quercitrin (97\%, SigmaAldrich), salicylic acid (99\%, Sigma-Aldrich), p-coumaric acid (98\%, Sigma-Aldrich), luteolin-7-O-glu (99\%, AppliChem), rosmarinic acid (96\%, Sigma-Aldrich), pyrogallol (98\%, Sigma-Aldrich), apigenin (95\%, Sigma-Aldrich), kaempferol (96\%, Sigma-Aldrich), and isorhamnetin (98\%, ExtraSynthese, Genay-France).

\section{LC-MS/MS experiments}

Due to its fragmented ion stability, the best mobile phase solution was determined to be a gradient of acidified methanol and water system. The optimum ESI parameters were determined as 2.40 mTorr CID gas pressure, $5000.00 \mathrm{~V}$ ESI needle voltage, $600.00 \mathrm{~V}$ ESI shield voltage, $300.00{ }^{\circ} \mathrm{C}$ drying gas temperature, $50.00^{\circ} \mathrm{C}$ API housing temperature, 55 psi Nebulizer gas pressure, and 40.00 psi drying gas pressure.

\section{Procedures of Biological Activity Assays}

\section{Determination of the Anticholinesterase Activity}

Inhibitory activities of acetyl- and butyryl-cholinesterase were measured by slightly modified spectrophotometric method, developed by Ellman, Courtney, Andres and Featherston (1). Acetylthiocholine iodide and butyrylthiocholine iodide were used as substrates of the reaction and DTNB method was used for the measurement of the anticholinesterase activity. Hundred and fifty microlitres of $100 \mathrm{mM}$ sodium phosphate buffer $(\mathrm{pH} 8.0)$, test tea samples at different concentrations. Solution of AChE or BChE were mixed and incubated for $15 \mathrm{~min}$ at $25^{\circ} \mathrm{C}$, and $0.5 \mathrm{mM}$ DTNB was added. The reaction was then initiated by the addition of acetylthiocholine iodide $(0.71 \mathrm{mM})$ or butyrylthiocholinechloride $(0.2 \mathrm{mM})$. The hydrolysis of these substrates were monitored spectrophotometrically by the formation of yellow 5-thio-2-nitrobenzoate anion as a result of the reaction of DTNB with thiocholine, released by the enzymatic hydrolysis of acetylthiocholine iodide or butyrylthiocholine chloride, at a wavelength of $412 \mathrm{~nm}$. Methanol was used as a solvent to dissolve the controls. Percentage of inhibition of AChE or BChE was determined by a comparison of the rates of reaction of samples relative to blank sample (ethanol in phosphate buffer $\mathrm{pH}$ 8.0) using the formula:

$$
\text { Inhibition } \%=[(E-S) / E] \times 100
$$

where $\mathrm{E}$ is the activity of enzyme without test sample. and $\mathrm{S}$ is the activity of enzyme with test sample. Galanthamine was used as a reference compound. 
Determination of the Antioxidant Activity with the $\beta$-Carotene Bleaching Method (2)

$\beta$-Carotene $(0.5 \mathrm{mg})$ in $1 \mathrm{~mL}$ of chloroform was added to $25 \mu \mathrm{L}$ of linoleic acid, and $200 \mathrm{mg}$ of Tween 40 emulsifier mixture. After evaporation of chloroform under vacuum, $100 \mathrm{~mL}$ of distilled water saturated with oxygen, was added through vigorous shaking. A mixture of four thousand microliters was transferred into different test tubes containing different concentrations of the sample. As soon as the emulsion was added to each tube, the zero-time absorbance was measured at $470 \mathrm{~nm}$ using a spectrophotometer. The emulsion system was incubated for $2 \mathrm{~h}$ at $50{ }^{\circ} \mathrm{C}$. A blank, devoid of $\beta$-carotene, was prepared for background subtraction. BHT (butylated hydroxytoluene) and BHA (butylated hydroxyanisole) were used as standards. The bleaching rate $(R)$ of $\beta$-carotene was calculated using the following equation: $R=\ln (a / b) / t$, where:

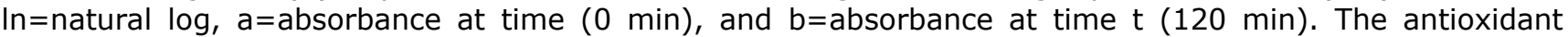
activity $(A A)$ was calculated in terms of percent inhibition relative to the control, using the equation below:

$$
A A=[(\text { Rcontrol - Rsample }) / \text { Rcontrol }] \times 100
$$

\section{Determination of Antioxidant Activity with the DPPH Free Radical Scavenging Method (3)}

The free radical scavenging activity of the methanol extract was determined spectrophotometrically by the DPPH (1.1-diphenyl-2-picrylhydrazyl) assay. In its radical form, DPPH absorbs at $517 \mathrm{~nm}$, but upon reduction by an antioxidant or a radical species, its absorption decreases. Briefly, $0.1 \mathrm{mM}$ solution of DPPH in methanol was prepared and $160 \mu \mathrm{L}$ of this solution was added to $40 \mu \mathrm{L}$ of sample solutions in methanol at different concentrations. After $30 \mathrm{~min}$, the absorbance was measured at $517 \mathrm{~nm}$. The lower absorbance of the reaction mixture indicates the higher free radical scavenging activity. The capability of scavenging the DPPH radical was calculated using the following equation:

$$
\text { DPPH scavenging effect }(\%)=\left[\left(A_{\text {control }}-A_{\text {sample }}\right) / A_{\text {control }}\right] \times 100
$$

\section{The CUPRAC Experiment (4)}

The CUPRAC method was performed as described. with some minor modification. since experiments were performed 96-well plates.

Briefly, $1 \mathrm{mM}$ dimethylformamide (DMF), $10 \mathrm{mM} \mathrm{CuCl}_{2}, 7.5 \mathrm{mM}$ neocuproine, $1 \mathrm{M} \mathrm{NH}_{4} \mathrm{CH}_{3} \mathrm{COO}(\mathrm{pH} 7.0)$ solution, and distilled water were mixed in a volume ratio of $1: 1: 1: 0.6$. Then, $180 \mu \mathrm{L}$ of the mixture was dispersed into the wells. $25 \mu \mathrm{L}$ diluted compounds (dilution ratio 1:20) in EtOH. After waiting for 30 minutes, the absorbance at $450 \mathrm{~nm}$ was measured against a reagent blank by Beckman Coulter DTX 880 Multimode Detection System. Ethanol was used as a negative control; whereas curcumin was used as a positive control.

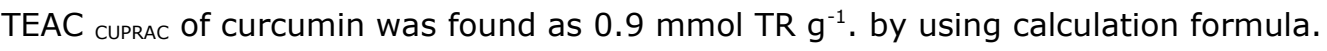

TEAC cUPRAC values of compounds were calculated by using references. TEAC of plant extracts ( $\mathrm{mmol}^{\mathrm{TR}} \mathrm{g}^{-1}$ ) $=\left(\right.$ Absorbance $\left./ \varepsilon_{\mathrm{TR}}\right)(205 / 25)(20 / 1)(2 / 0.02)$. Here, absorbance comes from the instrument; $\varepsilon_{\mathrm{TR}}=16700$ (1); 205 is total reaction volume; 25 is compound volume added to the reaction; 20/1 is the dilution factor; 2 is the solvent volume $(\mathrm{mL})$ in which plant extracts; 0.02 is weight of plant extract as grams.

\section{REFERENCES}

1. Ellman GL. Courtney KD. Andres V. Featherstone RM. A new and rapid colorimetric determination of acetylcholinesterase activity. Biochem Pharma. 1961; 7:88-95.

2. Marco GJ. A rapid method for evaluation of antioxidants. J American Oil Chem Soc. 1968; 45:594-8.

3. Blois MS. Antioxidant determinations by the use of a stable free radical. Nature. 1958;181:1199-1200.

4. Apak R. Güclü K. Özyürek M. Celik S E. Mechanism of antioxidant capacity assays and the CUPRAC (cupric ion reducing antioxidant capacity) assay. Microchimica Acta. 2008;160(4):413-9. 
CARIKCI S. JOTCSA. 2020; 7(2): 617-634.

RESEARCH ARTICLE 